\title{
The factors driving the synergy value in mergers of mechanical engineering companies in the Czech Republic
}

\author{
Mária Režňáková \\ Faculty of Business and Management \\ Brno University of Technology \\ Czech Republic \\ reznakova@fbm.vutbr.cz.

\section{Jan Pěta} \\ Faculty of Business and Management \\ Brno University of Technology \\ Czech Republic \\ peta@fbm.vutbr.cz.
}

Abstract. Research into factors that influence the outcome of mergers and acquisitions conducted over a few past decades focused on two areas, one being the forecasting of the volume of expected investments, the other investigating M\&A efficiency, i.e. the search for the factors that drive the growth of value of combined firms (identification of the sources of synergy). Operating synergies, resulting from cost savings and investment reduction, are deemed the primary source of synergy. Determining the synergy value is a prerequisite for identifying sources of savings. This paper presents the results of research aimed at determining the synergy value and identifying the factors representing potential sources of synergy. The discounted capital cash flow method was used to determine the synergy value. In the set of 50 mergers carried out between 2004 and 2011 that we investigated, we found that a negative synergy effect developed at an average level of $8.13 \%$. This means that most of these mergers were not associated with additional profits for the owners. The correlation between the selected financial ratios and the synergy value was tested. The results show that there is a statistically significant relationship between the indicators based on cash flow and the synergy value.

Keywords: mergers in mechanical engineering, effect of mergers, operating synergies, capital cash flow, value of synergies, Czech Republic.

JEL Classification: G32, G34, L2 


\section{INTRODUCTION}

The number and the value of mergers worldwide has been on the increase. The historical peak in the volume of completed mergers, namely USD 3.870 billion (MERGERMARKET, 2018) came in 2015. In the CEE region, the top three most active countries in terms of the number and value of completed mergers were the Czech Republic, Poland and Turkey. Since 2012, the Czech Republic has been the most active country in terms of the share of the value of completed mergers in the gross domestic product where that share has been fluctuating between 4 and $7 \%$, while staying beneath $3 \%$ in the other CEE countries (see Fig. 1). The exceptions were Poland (5.7\% in 2011) and Slovakia (4.4\% in 2012).

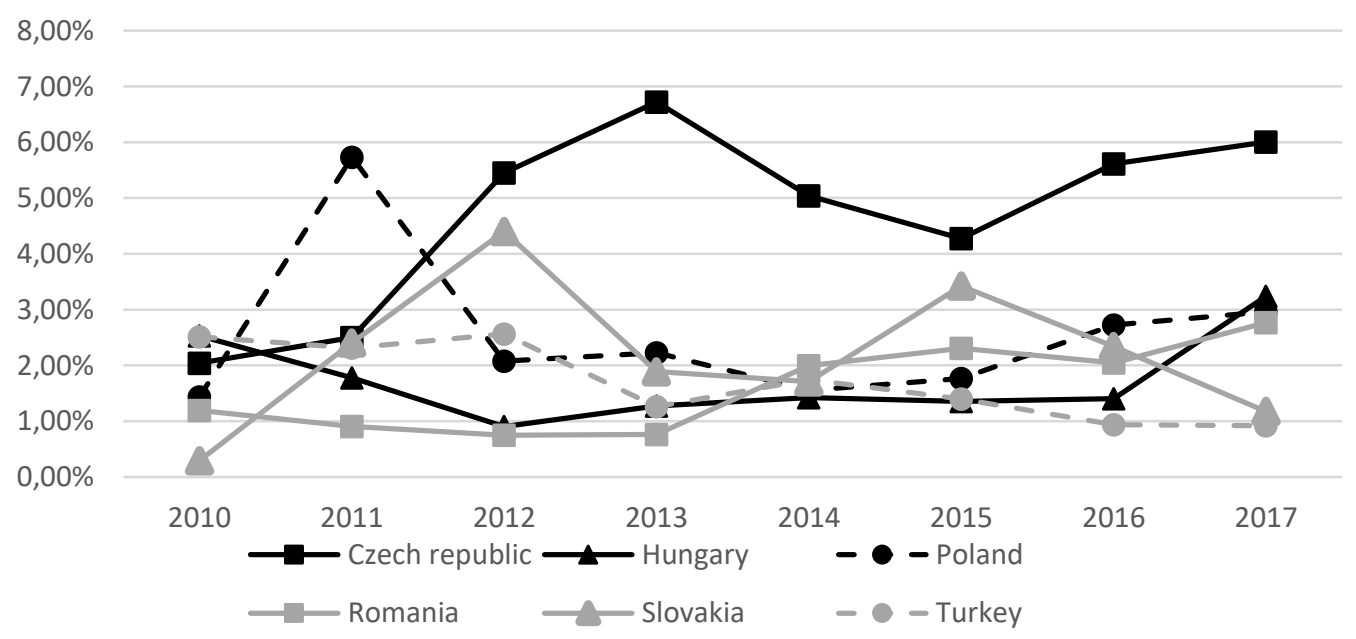

Figure 1. The Share of Mergers and Acquisitions in GDP

Source: Authors' construction from data from the EY $(2012,2014,2016,2018)$ and

EUROSTAT (2018)

The reason for company mergers is to achieve synergies leading to value growth, i.e. to increase the value of both the target and acquiring firm. However, the sources of the growth in the value of the merged companies remain unclear. Some authors assumed that the sources of synergy creation were associated with the economies of scale achieved by the merger. Mellen and Evans (2010, p. 84) stated that the source of synergy consists of cost savings due to consolidated functions, positions and long-term assets resulting in a decline in overheads. Also, Brealey et al. (2008) state that merged companies can integrate management, accounting, financial control or development, i.e. savings can occur in particular in indirect costs. In the 1960s, the predominant idea was that mergers were motivated by an endeavour to build a larger company with a diversified portfolio of products, which would be less sensitive to fluctuations in the business cycle. Portfolio diversification is mainly typical for congeneric and conglomerate mergers (Rock et al., 1994; Lipton, 2006; Gaughan, 2007; Martynova \& Renneboog, 2008; North, 2009). In the 1980s, the idea that the bidders acquire an additional cash flow through the merger from which they can repay their debts to the bank, and that the acquisition can be funded by issuing bonds, became more popular. In this context, Chatterjee (1986) stated that mergers and acquisitions allow for a reduction in capital costs, and this results in savings on income tax. These are referred to as financial synergy effects. Later, the focus of discussions about value creation sources shifted towards management efficiency. Trautwein (1990) introduced the concept of managerial synergies arising when the bidder's managers have better planning and monitoring skills. Vyas et al. (2012) interpret managerial synergies as the capacity to monitor and achieve goals. 
The aim of our research was to identify the sources of synergies resulting from the mergers of mechanical engineering companies in the Czech Republic.

\section{LITERATURE REVIEW}

\subsection{Sources of value created through mergers}

Our literature review identified two basic reasons for the growth of company value after a merger. The first reason is an increase in the operating profit margin, which can be achieved at the expense of suppliers, customers or employees (i.e. the transfer of profit from the stakeholders to the shareholders) and/or savings of invested capital. The transfer of profits from customers and suppliers results from a significant increase in the market power of the merged company, which will substantially affect input and output prices. The other reason is income tax savings, i.e. tax reasons. In this case, this involves additional value creation due to a change in the manner of funding the company after the merger. Value creation takes the form of the transfer of wealth from the government to the merging firms. Financial motives (including tax motives) as a potential reason for mergers are mentioned by, e.g., Ruback and Jensen (1983).

According to Mukherjee et al. (2004), who investigated the sources of synergies among managers of companies merging in 1990-2001, the majority of executives stated operating synergies as the motive of the merger, i.e. economies of scale. Only $10 \%$ of them stated financial synergy and growth in market power as the motives for the merger.

\subsection{Identifying operating synergies}

The authors who studied operational performance of companies before and after the transaction focused on examining the development of various financial indicators before and several years after the merger. They usually focused on publicly listed companies and either monitored their financial ratios (on the basis of financial statements) or used their discounted cash flow. These authors assumed that companies following a merger should achieve an improvement in cash flow due to an increase in the operating margin, an increase in asset turnover, or a reduction in labour costs (see, e.g., Healy et al., 1992; Houston et al., 2001; Harford, 2005; Huyghebaert \& Luypaert, 2010; Bernile \& Bauguess, 2011; Sedláček et al., 2013; Shim, 2011; Sorensen, 2000; and others). More recently, researchers used alternative approaches to synergy research. Bernile and Bauguess (2011) used changes in analysts' forecasts to assess the potential effect of M\&A. They used publicly available forecasts and found that the reasons for merger in $87.9 \%$ of M\&A transactions were operational synergies, such as cost savings due to layoffs, the combination of production capabilities and administrative functions, increased purchasing power in input markets, and elimination of redundant $R \& D$ and capital expenditure programmes. Revenue increases were expected rarely (in only $4.7 \%$ of forecasts). In terms of time, approximately a quarter of forecasts expected a payback between the second and fourth year; almost half of the forecasts did not contain any time factor.

Devos et al. (2009) selected a similar approach. Using Value Line Estimates of the potential effect of the M\&A, they found that the average total synergy in their sample was $10.03 \%$ scaled by the combined pre-merger equity value of the merging firms. The average financial synergy in the form of interest tax shields was only $1.64 \%$ (less than $17 \%$ of the total synergies). The merger-related synergy thus occurred as a result of operating synergies. However, this was not due to an increase in market power (an increase in revenues or cost savings), but rather to economies in their capital expenditures and investments in 
working capital. This type of synergy can only be achieved in the case of vertical and horizontal mergers; it does not occur in the case of congeneric mergers and conglomerate mergers (diversifying mergers). In addition, the authors found that the amount of savings generated by lower investments correlated positively with the level of investment before the merger.

These alternative approaches are limited by the existence of detailed company-specific forecasts in the various industries. If such forecasts are not available, researchers must resort to deriving the necessary data from financial statements from previous periods. In these cases, it is necessary to decide whether synergies will be identified using financial ratios or the present value of cash flow will be used to determine the synergy value. Using the first approach (i.e. financial ratios) in our previous work (Režňáková, \& Pěta, 2016), we found that the main sources of synergy creation were revenue growth and savings in payroll and depreciation expenses. In this follow-up study, we chose an alternative method for the calculation of the synergy effect based on determining the value of the companies before and after the merger. We then sought a correlation between the financial ratios and the resulting synergy value.

\subsection{The value of synergy}

According to the neoclassical theories, the value of a company and the value of the synergy achieved through the combining of companies are usually determined on the basis of the discounted cash flow. The value of synergy is then determined as the difference between the value of the company after the merger and the sum of the values of the stand-alone companies before the merger, i.e. Value of Synergy $=$ Value(AT) - (Value(A) + Value(T)). This approach was applied by, e.g., Ismail (2011), who used the discounted cash flow to calculate the company value. He calculated it three years after the merger and found that the merged companies value was $11.3 \%$ higher than was the sum of values of the two companies one year before their merger. In his study, the author used data on publicly listed US companies from January 1985 to April 2004. Houston et al. (2001) quantified the synergy effect on the basis of the present value of the earnings increments arising from increased sales, after-tax cost savings, and restructuring costs. They found that the average estimated present value of the merger gains as a percentage of the combined bidder and target's market value was $13.06 \%$.

Another approach found in the literature is based on the analysis of synergy forecasts by insiders at the merging firms published at the time of merger preparation. This approach was used by Bernile and Bauguess (2011). They presumed that insiders' incentives to provide synergy forecasts are affected by many aspects of the M\&A process, e.g. the need to obtain an approval from shareholders and regulatory agencies, competition by other potential bidders, and the existence of proprietary, litigation and/or reputation costs. Their results showed that in almost $90 \%$ of cases, the managers explicitly forecast cost savings resulting from the elimination of duplicate costs, the combination of production capabilities and administrative functions, increased purchasing power on input markets, and the elimination of capital expenditure programmes. They conducted research into M\&A deals between publically listed companies in the US announced between 1990 and 2005. The expected synergy value was determined using the method of discounted free cash flow based on managers' forecasts of the merging firms (for more information, see Bernile \& Bauguess, 2011).

The most common approach to business valuation on the basis of cash flow forecasts is based on the free cash flow (FCF) calculated as the difference between net operating profit after tax and net operating investment (see Koller et al., 2005, p. 164; Damodaran, 2002; Mařík, 2011, p. 455; and others).

In 2002, Richard S. Ruback presented the capital cash flow (CCF) method for valuing risky cash flows (see Ruback, 2002). He proved that once certain prerequisites have been met, this method produces the same results as the method based on free cash flow forecast. The difference between the two methods 
lies in how they assess tax shields: in the free cash flow method, the tax shield is in the cost of capital (i.e. in a discounted rate); in the capital cash flow method, the tax shield is included in the cash flow (see Kaplan \& Ruback, 1995; Gilson et al., 2000; Ruback, 2002). The capital cash flow approach is easier to apply when the level of debt changes or when a specific amount of debt is projected. As already mentioned, the motive for merger may also be the synergy effect resulting from a change in the capital structure. For this reason, the CCF method may be appropriate for determining the value of merging companies. Devos et al. (2009) also used this approach in their research.

In most cases, the literature review implies that the value of synergies is based on discounted cash flow that takes the form of free cash flow or capital cash flow. The use of the capital cash flow method seems appropriate for the purposes of forecasting synergies. Conclusions from previous studies served as an inspiration for our research aimed at determining the synergy value and identifying synergy sources. Since we did not have any forecasts of synergy effects created by mergers from insiders or specialised analytical groups, we had to determine the value of companies based on post-merger developments, and to compare it with the sum of the values of the merging companies. The synergy value was then analysed with respect to the potential sources of synergy determined based on the literature review. In this way, we were able to identify the decisive factors driving the synergy value.

\section{METHODOLOGY AND DATA}

In our research, we focused on examining factors influencing the value of synergy effects realised through mergers based on the following assumption (research hypothesis):

Certain financial ratios attain different values in companies where positive synergies were created through mergers and in companies where negative synergies were created. These ratios can be considered the sources of synergy.

We used the following procedure to verify the above hypothesis and to identify those synergy sources:

- First, in each merger case, we assigned a value to the acquiring company and the target company at the beginning of the year of the merger, i.e. when their values were not affected by the merger completion ${ }^{1}$. The computation of the value of the acquiring $\left(\mathrm{V}_{\mathrm{A}}\right)$ and target $\left(\mathrm{V}_{\mathrm{T}}\right)$ companies was based on the assumption that the companies would operate in the same manner in the future as they did in the past (stand-alone principle). The sum of values of merging companies represents the theoretical value of the newly created company without synergy $\left(\mathrm{V}_{\mathrm{A}}+\mathrm{V}_{\mathrm{T}}\right)$.

- The value of the combined company was then determined on the basis of the actual development following the merger $\left(\mathrm{V}_{\mathrm{AT}}\right)$.

- The results were used to calculate the synergy value, which was defined as the difference between the value of the combined company and the sum of the values of the stand-alone companies entering the merger, i.e. $V_{A T}-\left(V_{A}+V_{T}\right)$. If the synergy value was positive, the merger was classified as a success, i.e. creating value for shareholders. If the synergy value was negative, the merger was classified as a failed merger.

\footnotetext{
1 The value was determined as of 1 January of the year in which the merger took place (this year is designated " $t=0$ ") which is identical to the value determined as of 31 December of the previous year $(t=-1)$, i.e. at the end of the year before the merger. For the purposes of avoiding ambiguities, the designation "year before the merger" or " $t=-1$ " will be used.
} 
- We then analysed the two groups of mergers in order to identify the synergy factors, i.e. we were looking for the differences in the values of selected financial ratios between the companies that showed positive synergies after merger and those with negative synergies after merger.

The correlation was tested using the Kendall tau correlation coefficient, which is the non-parametric sequence correlation test. It is calculated on the basis of the number of concordances $(K)$, which is the number of observations characterised by the parameters $x, j$ (in our case, the ratio value and the synergy value), where $x_{i}>x_{j}$ and $y_{i}>y_{j}$; or if $x_{i}<x_{j}$ and $y_{i}<y_{j}$. Otherwise, it is a discordance $(D)$. The correlation coefficient is then calculated using the following formula:

$$
\text { Kendall tau coefficient }=\frac{K-D}{K+D}
$$

The coefficient determines the probability that values of two criteria will develop equally (Hendl, 2012). This test was chosen based on the comparison of nonparametric correlation tests performed by Croux and Dehon (2010). According to these authors, the Kendall's tau correlation coefficient is more robust and also more efficient than the Spearman's rank correlation coefficient. Another reason for using this test are the findings of Dehling et al. (2017), who stated that the Kendall's tau test is particularly suitable for small research data sets, and they considered it appropriate for the analysis of financial ratios. Statistica software was used for testing.

\subsection{Data used}

In an effort to eliminate the divergent developments in various industries, we focused on examining the efficiency of mergers in one industry only. The following criteria were set for determining the research sample:

- the merger was conducted by companies located in the Czech Republic from 2004 to 2011.

- it was the company's only merger in 7 years (three years before the merger, the year of the merger, and three years after the merger). The period from which we analysed companies' data was from 2001 to 2014. This length was selected in accordance with previous research (see Devos et al., 2009; Ismail, 2011; Sedláček et al., 2013).

- The financial statements of the target and acquiring company are publicly available (published at www.justice.cz).

According to the Bisnode database, 614 mergers meet the criteria defined above. Almost one third of the mergers were carried out by companies in the manufacturing industry. In the Czech Republic, it generates almost $40 \%$ of gross value added, provides employment for $26 \%$ of the working population, and is comprised of 24 highly diverse sectors. In our research, we focused on two of them, namely the manufacture of metal structures (CZ-NACE 25) and the manufacture of machinery and equipment (CZNACE 28), because they were the sectors with the largest number of mergers . Our criteria were met by 50 mergers in the two sectors involving 102 companies.

\subsection{Determining the synergy value}

The value of synergies consists in the increase in the value of two standalone companies after their merger. It thus represents the difference between the value of the companies after the merger and the sum of the companies' values before the merger. In order to calculate it, it was first necessary to determine the value of each of the merging companies, i.e. to establish the value of 102 companies before the merger. Then it was necessary to calculate the value of 50 merged companies. The value of the companies (both 
before and after the merger) was determined using the capital cash flow method (Devos et al., 2009; Ruback, 2002). We calculated the capital cash flow according to the following formula:

$$
C C F=[S \cdot O M \cdot(1-T)]-\Delta F A-\Delta N W C+I \cdot T \cdot D
$$

Where $\mathrm{S}$ means sales, $\mathrm{OM}$ is the operating margin, $\mathrm{T}$ is the income tax rate, $\Delta \mathrm{FA}$ is the annual increase of fixed assets per year (which represents the net investment in fixed assets), $\triangle \mathrm{NWC}$ is the investment of the net working capital, and I means interests on bank loans.

The value $S \cdot O M \cdot(1-T)$ represents after-tax operating profits and $I \cdot T \cdot D$ is the interest tax shield. This method is a modification of approach by Devose et al. (2009).

To compute the value, forecasts of the relevant parameters entering into the valuation are required:

Sales and operating profit margin (share of operating profits in sales) were forecast on the basis of the data for three years before the merger.

The income tax rate corresponds to the rate applicable in the year of the merger. This approach corresponds to the German valuation standard IDW S1 and was selected in line with the recommendation of Maŕík (2011, p. 29).

Investments in fixed assets were forecast based on the coefficient of the investment intensity of fixed assets based on the average from the share of fixed assets in sales for three years before the merger (see Mařik, 2011, p. 137). Subsequently, the difference between the forecast value of fixed assets in the current year and their value in the previous year was calculated.

Investments in the net working capital were determined in a manner similar to the investments in fixed assets.

Interest expenses were determined as the average of the interest for the three years prior to the merger. Our assumption was that the structure of funding sources for stand-alone companies would not change in the forecast period, i.e. the future interest expenses will be the same as the historical average.

The company value was calculated for each company as of 31 December of the year $t-1$, i.e. the year before the merger, using the following formula:

$$
\begin{gathered}
V_{A} \text { or } V_{T}=\sum_{t=0}^{3} \frac{C C F_{t}}{(1+i)^{t}}+\frac{T V}{(1+i)^{t+4}} \\
T V=C C F_{t+3} \cdot\left(1+\operatorname{Inf} f_{C Z}\right) \cdot \frac{1}{\left(i-\operatorname{Inf} f_{C Z}\right)}
\end{gathered}
$$

Where: $C C F t$ - capital cash flow forecast for each year (year " $e$ "); $t$ - year of forecast; $T V-$ terminal value of capital cash flows; $i$ - discounted rate (cost of equity); Inf $f_{c z}$ - inflation in the Czech Republic.

The terminal value of capital cash flow (TV) was determined in accordance with Devos et al. (2009) with the stable rate of its growth at the level of expected inflation. In our research, inflation was calculated on the basis of the values of the International Monetary Fund for the Czech Republic.

According to Devos et al. (2009), firms could be attracted by the opportunity to fully utilise tax shields, increase leverage, and exploit other tax benefits that increase profit for the owners. For this reason, the calculation of the present value of future cash flows uses the cost of equity. Their calculation was based on the Capital Assets Pricing Model (CAPM). Since we calculated the value of non-public companies, we used the beta coefficient of investors who are unable to diversify their portfolios by investing in the capital market, i.e. the total beta (Damodaran, 2012). The valuation procedure was the same in all 102 companies. 
The decision whether a merger created synergies was based on the calculated value of combined companies. The value of each combined company was calculated using the results achieved within three years of merger. In this way, we obtained three sets of values: two pre-merger values of the stand-alone merging firms and one set for the post-merger combined firm.

Subsequently, the synergy value was calculated according to the following formula: $V_{A T}-\left(V_{A}+V_{T}\right)$, i.e. the difference between the value of the combined company (the real value of combined company) and the sum of values of the stand-alone acquiring and target firms (the theoretical value of combined company). The procedure for determining the synergy value for all 50 mergers was identical.

According to the synergy value, the companies were divided into a group of successful mergers (which created positive synergies) and a group of failed mergers (those that created negative synergies). Within these groups, the development of selected financial ratios was analysed and the differences in their development were identified. In addition, correlation between the synergy value and the analysed indicators was tested. The following indicators were analysed:

Material consumption to sales ratio. This indicator measures whether the ratio of prices of purchased inputs (materials, energy or services) to sales changed in post-merger period. If it decreased, the company was achieving savings due to its increased market power, i.e. its bargaining power vis-a-vis their business partners (see Houston et al., 2001; Devos et al., 2009; Ficbauer \& Režňáková, 2014).

Assets turnover. Healy et al. (1992) and Devos et al. (2009) mention the importance of this indicator.

Labour costs to sales ratio. The combined companies may consolidate certain functions. As mentioned by Brealey et al. (2008) and Bernile and Bauguess (2011), it is possible to merge management, accounting, financial auditing, or research and development expenditure.

Investments and depreciation to sales ratios. The combined company should consolidate its assets and dispose of any unnecessary assets (see Mellen \& Evans, 2010). Similarly, the utilization of fixed assets is expected to improve (and the reduction in the proportion in fixed cost in sales). Devos et al. (2009) considers investment savings a primary source of synergy. Povolná and Švarcová (2017) also emphasise the importance of investments in engineering.

Return ratios. These indicators were used, e.g., by Sorensen (2000), Harford (2005), Shim (2011) and Asimakopoulos and Athanasoglou (2013).

Leverage ratio and the ratio of bank loans to assets. The companies using debt financing of the transaction may reduce their tax base by increasing the share of debt financing (see Huyghebaert \& Luypaert, 2010). Because financing companies through bank loans is more common in the Czech Republic than through issuing bonds, the bank loans to assets ratio was analysed (see, for example, Mačí \& Valentová Hovorková, 2017).

Cash flow-based ratios. The aforementioned ratios should ultimately be reflected in the cash flow increment. This is in line with the data published by Sorensen (2000), who found that values of cash flowbased ratios were significantly different in the companies that carried out a merger.

\section{RESULTS AND DISCUSSION}

First, the target, the acquiring and the newly combined companies were valued according to the above procedure. The forecasting of investments in fixed assets and of the net working capital of the stand-alone companies (before merger), participating in the merger was rather complicated. Some companies showed an abnormal investment activity in the pre-merger period leading to a substantial increase in assets. It is impossible, and frequently not even desirable, to maintain that high investment activity in the future, as it could lead to insufficient use of production capacity or to keeping excessive inventories, receivables or cash. In addition, we were justified to assume that some of the companies had 
redundant assets. This made us perform some corrections in investment forecasts in the case of a high proportion of fixed assets in sales or because of a significant change in NWC investments. The corrections were made by adjusting the fixed assets ratio and net working capital to sales.

Adjustments to the investment intensity to net working capital and fixed assets were carried out based on the median value of all companies divided into bidder and target groups, as shown in Tab. 1.

Table 1

Descriptive statistics of investment intensity coefficients

\begin{tabular}{|c|c|c|c|c|c|c|c|}
\hline & & Min & $\begin{array}{l}\text { Lower } \\
\text { quartile }\end{array}$ & Median & $\begin{array}{l}\text { Upper } \\
\text { quartile }\end{array}$ & Max & Std. dev. \\
\hline \multirow{2}{*}{$\begin{array}{l}\text { Target } \\
\text { firm }\end{array}$} & Fixed Assets/Sales & 0.0000 & 0.1095 & 0.3312 & 0.5158 & 16.6015 & 2.3327 \\
\hline & NWC/Sales & -4.3584 & 0.0577 & 0.1262 & 0.2998 & 6.7460 & 1.1761 \\
\hline \multirow{2}{*}{$\begin{array}{l}\text { Bidder } \\
\text { firm }\end{array}$} & Fixed Assets/Sales & 0.0000 & 0.1655 & 0.2509 & 0.4936 & 7.2266 & 1.2291 \\
\hline & NWC/Sales & -3.8448 & 0.0000 & 0.1308 & 0.3348 & 2.5093 & 0.8843 \\
\hline
\end{tabular}

Source: The authors' results

\subsection{Synergy value}

We used the real and theoretical values of combined companies to calculate synergy values. The results show that the value increased in 19 combined companies, i.e. they created positive synergies, and decreased in the remaining 31 combined companies, i.e. they created negative synergies. Table 2 shows the basic characteristics of the calculated synergy values.

Table 2

Descriptive statistics of the synergy value in the case of mergers

\begin{tabular}{|l|c|c|c|c|c|c|}
\hline & Min & $\begin{array}{c}\text { Lower } \\
\text { quartile }\end{array}$ & Median & $\begin{array}{c}\text { Upper } \\
\text { quartile }\end{array}$ & Max & Std. dev. \\
\hline All mergers & -0.9312 & -0.6718 & -0.3098 & 0.3536 & 1.5892 & 0.7063 \\
\hline $\begin{array}{l}\text { Unsuccessful mergers } \\
\text { (creating negative synergies) }\end{array}$ & -0.9312 & -0.8085 & -0.6480 & -0.3243 & -0.0643 & 0.2661 \\
\hline $\begin{array}{l}\text { Successful mergers } \\
\text { (creating positive synergies) }\end{array}$ & 0.1477 & 0.3429 & 0.6030 & 1.0771 & 1.5892 & 0.4219 \\
\hline
\end{tabular}

Source: The authors' results

The least successful merger was one in which $93 \%$ of the company's value was lost. Half of all the examined mergers produced a loss exceeding $31 \%$; on the other hand, a quarter achieved an increase of value exceeding $35 \%$. This difference is due to the positive synergy effects in successful mergers, with six of them achieving a synergy effect of more than $100 \%$. This was reflected in the median value of successful mergers, which grew by $60 \%$. The mean value of all synergies was negative $(-8.1 \%)$.

In addition, we also examined the differences in the selected indicators between companies achieving positive synergies and those with negative synergies.

\subsection{Synergy sources: What indicators acquire a different value before and after the merger?}

In accordance with the applied procedure, we focused on analysing some selected financial ratios during the entire period of investigation. Each indicator was examined three years before the merger, in 
the year of the merger $(\mathrm{t}=0)$, and three years after the merger. Due to the extent of the analysed data, Table 3 shows the descriptive characteristics of the indicators only in the year of the merger and three years after it.

Table 3

Descriptive statistics of the financial ratios of the examined sample

\begin{tabular}{|c|c|c|c|c|c|c|}
\hline \multicolumn{7}{|c|}{ Year of mergers $(t=0)$} \\
\hline & Min & $\begin{array}{l}\text { Lower } \\
\text { quartile }\end{array}$ & Median & $\begin{array}{l}\text { Upper } \\
\text { quartile }\end{array}$ & Max & Std. dev. \\
\hline $\begin{array}{l}\text { Production consumption/ } \\
\text { Sales }\end{array}$ & 0.0000 & 0.1023 & 0.1418 & 0.2013 & 0.3467 & 0.0845 \\
\hline Assets Turnover & 0.0000 & 0.0179 & 0.0389 & 0.0517 & 0.2194 & 0.0389 \\
\hline Labour Cost/ Sales & 0.0000 & 0.8672 & 1.2082 & 1.7539 & 5.2130 & 0.9848 \\
\hline Depreciation/Sales & 0.0000 & 0.4945 & 0.6181 & 0.7423 & 0.9834 & 0.1997 \\
\hline Return of Assets & -0.1760 & 0.0171 & 0.0770 & 0.1442 & 0.3680 & 0.1178 \\
\hline Return of Equity & -2.5986 & 0.0000 & 0.1494 & 0.2800 & 1.5283 & 0.7562 \\
\hline Cash/ Assets & 0.0000 & 0.0229 & 0.0636 & 0.1683 & 0.5570 & 0.1562 \\
\hline Leverage Ratio & 0.0000 & 0.2874 & 0.4995 & 0.7492 & 1.3079 & 0.2989 \\
\hline Bank Loans/ Assets & 0.0000 & 0.0000 & 0.1078 & 0.2250 & 0.9506 & 0.2063 \\
\hline Cash Flow/Assets & -0.1201 & 0.0381 & 0.1138 & 0.1856 & 0.5057 & 0.1163 \\
\hline Cash Flow /Interest & -22.7621 & 0.0000 & 3.6912 & 17.5030 & 105.4444 & 21.3003 \\
\hline Cash Flow /Sales & -0.1321 & 0.0387 & 0.0818 & 0.1311 & 0.6020 & 0.1271 \\
\hline Investment $(=\Delta \mathrm{FA})$ & -0.6649 & -0.2616 & -0.0203 & 0.1237 & 9.7077 & 1.4102 \\
\hline \multicolumn{7}{|c|}{ Three years after mergers $(t=3)$} \\
\hline & Min & $\begin{array}{l}\text { Lower } \\
\text { quartile }\end{array}$ & Median & $\begin{array}{l}\text { Upper } \\
\text { quartile }\end{array}$ & Max & Std. dev. \\
\hline $\begin{array}{l}\text { Production consumption/ } \\
\text { Sales }\end{array}$ & 0.0000 & 0.1085 & 0.1346 & 0.2229 & 0.3504 & 0.0950 \\
\hline Assets Turnover & 0.0000 & 0.0157 & 0.0336 & 0.0534 & 0.2030 & 0.0429 \\
\hline Labour Cost/ Sales & 0.0000 & 0.9478 & 1.2942 & 1.8355 & 3.4161 & 0.7446 \\
\hline Depreciation/ Sales & 0.0000 & 0.4876 & 0.6045 & 0.7508 & 1.3177 & 0.2087 \\
\hline Return of Assets & -0.1221 & 0.0417 & 0.0850 & 0.1607 & 0.5054 & 0.1177 \\
\hline Return of Equity & -4.4015 & 0.0722 & 0.1686 & 0.4067 & 1.0435 & 0.7172 \\
\hline Cash/ Assets & 0.0000 & 0.0129 & 0.0579 & 0.1501 & 0.9922 & 0.1721 \\
\hline Leverage Ratio & 0.0000 & 0.2941 & 0.4312 & 0.6872 & 1.0496 & 0.2596 \\
\hline Bank Loans/ Assets & 0.0000 & 0.0000 & 0.0556 & 0.2459 & 0.4224 & 0.1459 \\
\hline Cash Flow/Assets & -0.0889 & 0.0678 & 0.1296 & 0.1813 & 0.5330 & 0.1169 \\
\hline Cash Flow / Interest & -1.8750 & 0.9447 & 11.2175 & 48.3820 & 190.5556 & 55.0442 \\
\hline Cash Flow /Sales & -0.3542 & 0.0509 & 0.0972 & 0.1288 & 1.1956 & 0.2006 \\
\hline Investment $(=\Delta \mathrm{FA})$ & -0.4793 & -0.0304 & 0.0612 & 0.1426 & 1.5928 & 0.3517 \\
\hline
\end{tabular}

Source: The authors' results

The above values imply that the median of the labour cost to sales ratio dropped by 0.72 percentage points, with a simultaneous increase in the data variability (differences between companies). It is therefore obvious that cost savings were achieved because of a reduction in the number of workers, because no reduction of wages was recorded in the industry in question in any year of monitoring. The assets turnover ratio showed a very positive development. It increased on average by $8.6 \mathrm{pp}$, with a simultaneous significant decrease in standard deviation. The sales in the entire examined group grew on average by 8.06 
$\%$ three years after merger compared with the situation a year before the merger. These conclusions concur with previous research (see, e.g., Brealey et al., 2008; Bernile \& Bauguess, 2011).

Both return ratios (ROA and ROE) also improved: their values rose by $0.79 \mathrm{pp}$ and $1.92 \mathrm{pp}$, respectively, while standard deviation values remained unchanged. This is another manifestation of a synergy effect in the area of business efficiency improvement after merger. In his research, Sorensen (2000) also identified differences in the values of the return ratios. The leverage ratio and the loan to assets ratio declined in the examined period, with a simultaneous drop in the value of the standard deviation. This implies that the mergers were funded by neither bank loans nor any other loans. Our assumption formulated in line with Huyghebaert and Luypaert (2010) that financial synergies may also contribute to the resulting synergies was not confirmed. The cash flow to interest ratio increased significantly. The variability of this indicator increased substantially as well, which makes it rather difficult to evaluate the importance of this indicator in terms of its impact on synergy. Due to the fact that there was no increase in the share of bank loans in asset financing, it can be assumed that there may have been significant differences in the interest rates on loans between individual companies or an increase in the differences in operating profit margins between them. The other examined indicators do not show any significant changes.

The changes in the value of the indicators were further analysed separately in the group of companies creating positive synergies and in the group creating negative synergies. For this purpose, we used both box charts (see Fig. 2) and the absolute changes in the indicator values.
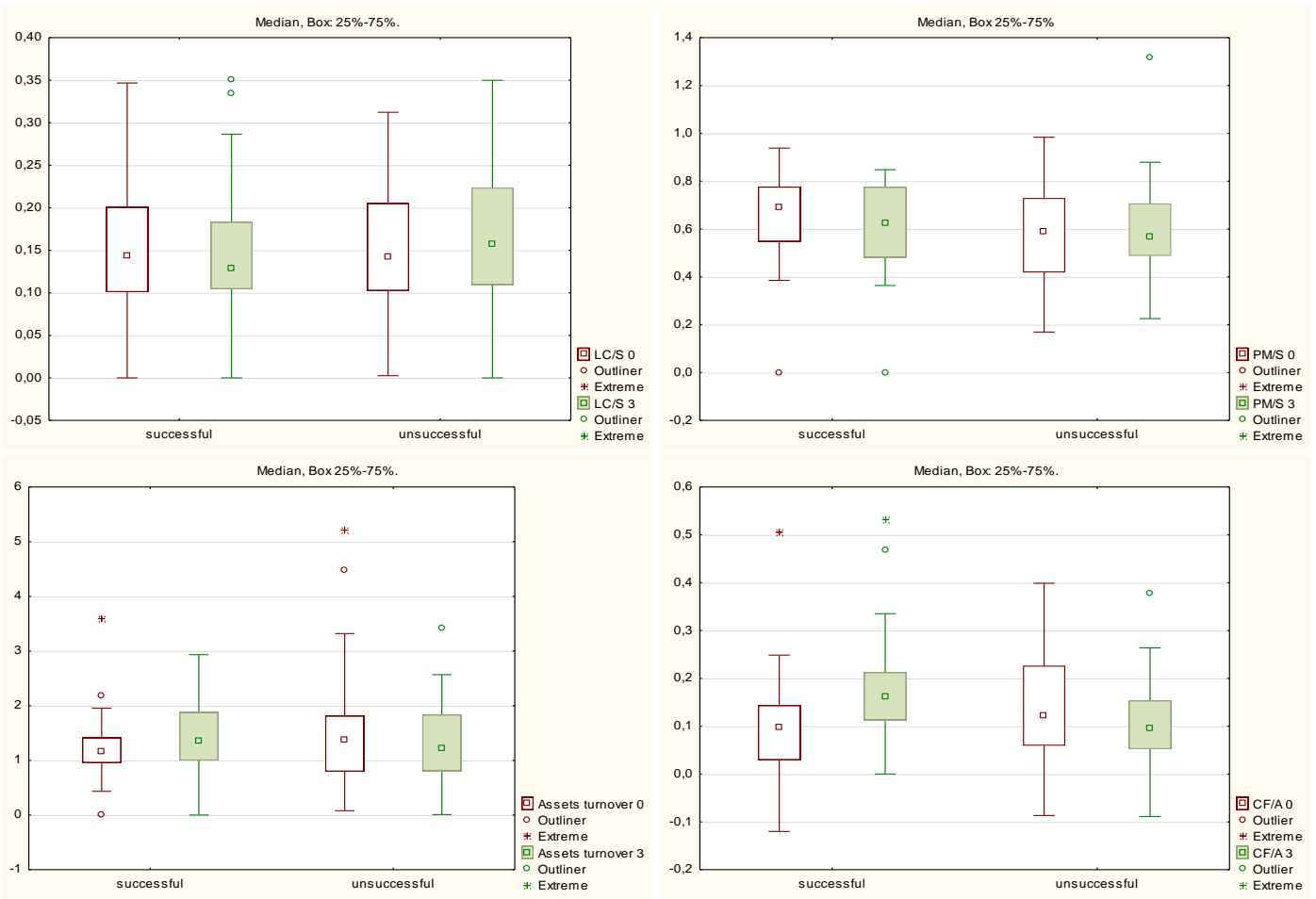

Figure 2. The development of the values of selected ratios in the groups of successful / unsuccessful mergers

Source: The authors' results

The figure shows that there was a decline in the median of the labour cost to sales (LC/S) indicator in successful mergers three years of the merger. We found that the value of the indicator fell by an average 
of $0.3 \mathrm{pp}$ in the group of companies creating positive synergy; this indicator increased by $1.7 \mathrm{pp}$ in mergers generating negative synergy. This implies that consolidation of jobs occurred in the group of companies with a positive value of synergies. This process generated cost savings and increased operating profit. The opposite situation was ascertained in the group of failed mergers.

The production consumption to sales (PC/S) ratio shows a decline in both groups; there is a slightly stronger decline in the companies generating positive synergy. An increase could only have been achieved by increasing the efficiency of the utilization of purchased inputs (i.e. materials, energy, services).

The profit margin of all the examined companies three years after merger increased by $44.4 \%$ compared to a year before merger. A year before the merger, the companies generated an average profit margin of $3.94 \%$, while three years after the merger, their profit margin was $5.69 \%$. In the group of companies generating positive synergy, profit margins grew from $3.14 \%$ to $7.11 \%$ (an increase of $126 \%$ ); in the group of companies generating negative synergy they decreased from $5.10 \%$ to $2.94 \%$ (a decrease of $42.45 \%$ ). These findings confirm our assumption about the higher efficiency of input and human resource utilisation in the group of companies generating positive synergy.

Also the assets turnover ratio developed differently in the two groups, increasing on average by 22.7 pp in combined companies creating positive synergies and decreasing by $20.7 \mathrm{pp}$ in the group of unsuccessful mergers. This is the most striking difference between the two groups of combined companies. The increase was due mainly to growing sales. In all the companies, sales grew on average by $8.06 \%$ compared to a year before merger. In the group of companies generating positive synergy, they grew by $18.83 \%$, but decreased by $8.05 \%$ in the group of companies generating negative synergy. The investments grew by $18 \mathrm{pp}$ in the group of mergers generating positive synergy and decreased by $16 \mathrm{pp}$ in the other group. This contradicts the conclusion reached by Devos et al. (2009) that investment savings are the main source of synergy. Our conclusion is confirmed by the fact that only minimum changes were found in the average value of the depreciation to sales ratio in either group.

The cash flow to assets (CF/A) ratio also developed differently. The value of this indicator grew by $9.1 \mathrm{pp}$ in the group of successful mergers, in contrast to a decrease of $2 \mathrm{pp}$ in the group of unsuccessful mergers.

In addition, we examined the correlation between the synergy value and the examined indicators before and after the merger. The aim was to find out whether it was possible to estimate the future effect of a merger on the basis of some indicators, and whether certain indicators will be markedly influenced by the merger effect. For this purpose, the Kendall tau correlation coefficient was used. Due to the large number of tested indicators for individual years, the following table shows only the statistically significant indicators at the $5 \%$ level. The results of the calculation are shown in Tab. 4.

A statistically significant relationship between the synergy value and the value of the selected indicator before the merger was found only in the case of four indicators, namely ROA, CF to Assets, CF to Interest and CF to Sales three years before the merger; and in two cases two years before the merger. A negative correlation was found in all these indicators. This may mean that the higher the value of an indicator three years before the merger, the lower the synergy value created. We do not attach much importance to this conclusion as this may be substantially influenced by the high variability of the tested indicators. What we perceive as more important are the conclusions arising from the assessment of the development of indicators by groups, i.e. in the group of companies creating positive synergies and in the group of companies creating negative synergies.

Although there is no statistically significant relation between the synergy value achieved by the merger and the majority of the examined indicators, there are substantial differences between the mean or median values of indicators in the companies depending on their synergy value (i.e. positive or negative). 
They are sales, labour cost to sales, operating margin, asset turnover and investment. These can be considered the sources of synergy creation.

Table 4

P-value and Kendall tau correlation coefficients of synergy values and selected indicators (statistically significant indicators)

\begin{tabular}{|l|c|c|c|}
\hline \multicolumn{1}{|c|}{ Indicator } & Kendall-Tau Correlation Coefficients & Z-score & p-value \\
\hline Return of Assets -3 & -0.2686 & -2.7520 & 0.0059 \\
\hline Return of Assets +3 & 0.2751 & 2.8190 & 0.0048 \\
\hline Cash/ Assets -3 & -0.2196 & -2.2502 & 0.0244 \\
\hline Cash Flow/Assets -3 & -0.2473 & -2.5346 & 0.0113 \\
\hline Cash Flow/Assets +2 & 0.2000 & 2.0494 & 0.0404 \\
\hline Cash Flow/Assets +3 & 0.2882 & 2.9528 & 0.0031 \\
\hline Cash Flow/Interest -3 & -0.4160 & -4.2625 & 0.0000 \\
\hline Cash Flow/Interest -2 & -0.2553 & -2.6162 & 0.0089 \\
\hline Cash Flow/Sales -3 & -0.2539 & -2.6015 & 0.0093 \\
\hline Cash Flow/Sales -2 & -0.2000 & -2.0494 & 0.0404 \\
\hline
\end{tabular}

Source: The authors' results

The above indicators have also been highlighted in the results of research conducted earlier. In particular, the short-term financial assets to assets ratio was considered an indicator of a successful merger by Huyghebaert and Luypaert (2010). The identification of the cash flow to assets ratio and cash flow to interest expense is consistent with the findings of Sorensen (2000), who believed that these the value of these ratios was significantly different in companies that had accomplished a successful merger. The impact on synergy creation in the cash flow to sales ratio was also confirmed by Harford (2005).

\section{CONCLUSION}

The literature review showed that there were two approaches that could be used to identify the sources of synergy in mergers. One was an analysis based of the financial ratios calculated from accounting data of companies before and after the merger, the other was based on the calculation of the synergy value of combined firms. We chose the latter for our research presented here, which, however, proved much more demanding. The authors who selected the same approach used data from the capital market to determine the synergy value, or they calculated the synergy value from forecasts of company development published by reputable companies (this approach was selected by Devos et al., 2009). In our research, we had neither of these sources of information available to us. Therefore, it was first necessary to determine the value of the companies before and after the merger and then to use those values to quantify the synergy value. The value of the companies before the merger was determined on the basis of a forecast of capital cash flow development while respecting the stand-alone principle. In order to eliminate the impact of the external environment on company development, we chose to limit our research to mergers in one industry only. The combined company value was determined on the basis of real capital cash flow after the merger. The synergy value was then determined as the difference between the combined company value and the sum of bidder and target stand-alone companies values. The authors of this study believe that their approach can be a methodology suitable for calculating the synergy value in studies involving companies that are not publicly traded and whose development forecasts are not publicly reported. 
Depending on the synergy value, we analysed the development of selected financial ratios. It was found that the average values of the indicators of sales, production consumption, operating margin, assets turnover and investments developed differently in the group of companies creating positive synergies and in the group of companies creating negative synergies. These indicators may be considered as the sources of synergies.

Most research has shown that mergers generate benefits by improving resource utilisation in the economy rather than by merely transferring wealth to stockholders from the government, customers or suppliers. The results of our research confirm this conclusion. Our findings are also corroborated by the fact that no merger carried out in the period monitored could have significantly affected competition in the industry.

\section{ACKNOWLEDGEMENT}

The authors are grateful to the Internal Grant Agency of University No.: FP-S-18-5234 "Prediction models in finance: analysis of factors and predictions of bankruptcy, company performance and value" for financial support to carry out this research.

\section{REFERENCES}

Asimakopoulos, I., \& Athanasoglou, P. P. (2013). Revisiting the Merger and Acquisition Performance of European Banks. International Review of Financial Analysis, (29), 237-249. doi: 10.1016/j.irfa.2012.08.010

Bernile, G., \& Bauguess, S. (2011). Do Merger-Related Operating Synergies Exist? Working Paper. SSRN Electronic Journal. doi: $10.2139 /$ ssrn.642322

Brealey, R. A., Myers, S. C., \& Allen, F. (2008). Principles of Corporate Finance (9th Ed.). Boston, Mass: McGraw-Hill.

Croux, C., \& Dehon, C. (2010). Influence Functions of the Spearman and Kendall Correlation Measures. Statistical Methods \& Applications, 19(4), 497-515. doi: 10.1007/s10260-010-0142-z

Damodaran, A. (2012). Total Beta Europe 11. Retrieved from: http://www.stern.nyu.edu/ adamodar/pc/archives/totalbetaEurope11.xls (16. 1. 2018).

Damodaran, A. (2002). Investment V aluation: Tools and Techniques for Determining the V alue of any Asset (2 $\left.{ }^{\text {nd }} \mathrm{Ed}.\right)$. New York: John Wiley.

Dehling, H., Vogel, D., Wendler, M., \& Wied, D. (2017). Testing for Changes in Kendall's Tau. Econometric Theory, 33(06), 1352-1386. doi: 10.1017/S026646661600044X

Devos, E., Kadapakkam, P. R., \& Krishnamurthy, S. (2009). How do Mergers Create Value? A Comparison of Taxes, Market Power, and Efficiency Improvements as Explanations for Synergies. Review of Financial Studies, 22(3), 1179-1211. doi: 10.1093/rfs/hhn019

EUROSTAT. (2018). Gross domestic product at market prices: At current prices. Eurostat. Retrieved from: http:/ / ec.europa.eu/eurostat/tgm/table.do?tab=table\&init=1\&plugin=1\&language=en\& pcode=tec00001 (17. 4. 2018).

EY. (2012). M\&A Barometer 2011: Central and Southeast Europe. Retrieved from: http://www.immoss.ro/usr/ imagini/2012/01/27/1481-ma-barometer-cse-europe-2011.pdf (17. 4. 2018).

EY (2014). M\&A Barometer 2013: Central and Southeast Europe. Retrieved from: http://mcr.doingbusiness.ro/ uploads/53315ff85c5a7MA\%20Barometer CSE 2013.pdf (17. 4. 2018).

EY. (2016). M\&A Barometer 2015: Central and Southeast Europe. Retrieved from: https://www.ey.com/ Publication/vwLUAssets/2016-MA-Barometer-CSE-2015/\$FILE/MA CSE barometer\%202015.pdf (17. 4. 2018).

EY. (2018). M\&A Barometer 2017: Central and Southeast Europe. Retrieved from: https://www.ey.com/ Publication/vwLUAssets/ey-csema-barometer-2017/\$FILE/ey-csema-barometer-2017.pdf (17. 4. 2018). 
Ficbauer, D., \& Režňáková, M. (2014). Holding Company and its Performance. Acta Universitatis Agriculturae et Silviculturae Mendelianae Brunensis, 62(2), 329-337. doi: 10.11118/actaun201462020329

Gaughan, P. A. (2007). Mergers, acquisitions, and corporate restructurings (4th Ed.). Hoboken, N.J.: Wiley.

Gilson, S. C., Hotchkiss, E. S., \& Ruback, R. S. (2000). Valuation of Bankrupt Firms. Review of Financial Studies, 13(1), 43-74. doi: $10.1093 / \mathrm{rfs} / 13.1 .43$

Harford, J. (2005). What Drives Merger Waves? Journal of Financial Economics, 77(3), 529-560. doi: 10.1016/j.jfineco.2004.05.004

Healy, P. M., Palepu, K. G., \& Ruback, R. S. (1992). Does Corporate Performance Improve after Mergers?. Journal of Financial Economics, 31(2), 135-175. doi: 10.1016/0304-405x(92)90002-f

Hendl, J. (2012). Prehled statistických metod: analýza a metaanalýza dat (4th Ed.). Prague: Portál.

Houston, J. F., James, C. M., \& Ryngaert, M. D. (2001). Where do Merger Gains Come from? Bank Mergers from the Perspective of Insiders and Outsiders. Journal of Financial Economics, 60(2-3), 285-331. doi: 10.1007/978-3662-04847-4

Huyghebaert, N., \& Luypaert, M. (2010). Antecedents of Growth through Mergers and Acquisitions: Empirical Results from Belgium. Journal of Business Research, 63(4), 392-403. doi: 10.1016/j.jbusres.2009.06.003

Chatterjee, S. (1986). Types of Synergy and Economic Value: The Impact of Acquisitions on Merging and Rival Firms. Strategic Management Journal, 7(2), 119-139. doi: 10.1002/smj.4250070203

Ismail, A. (2011). Does the Management's Forecast of Merger Synergies Explain the Premium Paid, the Method of Payment, and Merger Motives? Financial Management, 40(4), 879-910. doi: 10.1111/j.1755-053x.2011.01165.x

Kaplan, S. N., \& Ruback, R. S. (1995). The Valuation of Cash Flow Forecasts: An Empirical Analysis. The Journal of Finance, 50(4), 1059-1093. doi: 10.2307/2329344

Koller, T., Goedhart, M., \& Wessels, D. (2005). Valuation: Measuring and Managing the Value of Companies (4th Ed.). Hoboken, N.J.: John Wiley.

Lipton, M. (2006). Merger Waves in the 19th, 20th and 21st Centuries. The Davies Lecture, Osgoode Hall Law School, York University, (14), 21.

Mačí, J., \& Valentová Hovorková, V. (2017). Loan versus Bond Financing of Czech Companies and the Influence of the Global Recession. Journal of Competitiveness, 9(1), 72-88. doi: 10.7441/joc.2017.01.05

Martynova, M., \& Renneboog, L. (2008). A Century of Corporate Takeovers: What Have we Learned and Where Do we Stand? Journal of Banking, 32(10), 2148-2177. doi: 10.1016/j.jbankfin.2007.12.038

Mař́k, M. (2011). Metody oceňování podniku: proces ocenèni - základni metody a postupy (3 ${ }^{\text {rd }}$ Ed.). Prague: Ekopress.

Mellen, C. M., \& Evens, F. C. (2010). V aluation for M\&A: Building V alue in Private Companies (2nd Ed.). Hoboken, N.J.: Wiley.

MERGERMARKET. (2018). Global \& Regional M※A Report FY 2017. Retrieved from: https://www.mergermarket.com/info/2017-full-year-global-ma-trend-report-legal-advisors (17. 4. 2018).

Mukherjee, T. K., Kiymaz, H., \& Bake, H. K. (2004). Merger Motives and Target Valuation: A Survey of Evidence from CFOs. Journal of Applied Finance, 14(2), 7-24.

North, D. (2009). The Capitalist Crisis and the Return of History. Retrieved from http://www.wsws.org/en/articles/2009/03/dnor-m26.html (15. 10. 2017).

Povolná, L., \& Švarcová, J. (2017). The Macroeconomic Context of Investments in the Field of Machine Tools in the Czech Republic. Journal of Competitiveness, 9(2), 110-122. doi: 10.7441/joc.2017.02.08

Režňáková, M., \& Pěta, J. (2016). Efficiency of Mergers of Mechanical Engineering Companies in the Czech Republic. Review of Economic Perspectives, 16(4), 361-374. doi: 10.1515/revecp-2016-0020

Rock, M. L., Rock, R. H., \& Sikora, M. J. (1994). The Mergers and Acquisitions Handbook (2 ${ }^{\text {nd }}$ Ed.). New York: McGrawHill.

Ruback, R. S. (2002). Capital Cash Flows: A Simple Approach to Valuing Risky Cash Flows. Financial Management, 31(2), 85-103. doi: 10.2139/ssrn.223080

Ruback, R. S., \& Jensen, M. C. (1983). The Market for Corporate Control: The Scientific Evidence. Journal of Financial Economics, 11(1-4), 5-50. doi: 10.1016/0304-405X(83)90004-1 
Sedláček, J., Valouch, P., \& Konečný, A. (2013). Synergic Motives and Economic Success of Mergers of Czech Companies. Acta Universitatis Agriculturae et Silviculturae Mendelianae Brunensis, 61(7), 2721-2727. doi: $10.1787 / 888932629425$

Shim, J. (2011). Mergers \& Acquisitions, Diversification and Performance in the U.S. Property-Liability Insurance Industry. Journal of Financial Services Research, 39(3), 119-144. doi: 10.1007/s10693-010-0094-3

Sorensen, D. E. (2000). Characteristics of Merging Firms. Journal of Economics and Business, 52(5), 423-433. doi: 10.1016/s0148-6195(00)00028-x

Trautwein, F. (1990). Merger Motives and Merger Prescriptions. Strategic Management Journal, 11(4), 283-295. doi: 10.1002/smj.4250110404

Vyas, V., Narayanan, K., \& Ramanathan, A. (2012). Determinants of Mergers and Acquisitions in Indian Pharmaceutical Industry. Eurasian Journal of Business and Economics, 5(9), 79-102. 